\title{
Robust a-synuclein pathology in select brainstem neuronal populations is a potential instigator of multiple system atrophy
}

\author{
Ethan W. Hass 1,2, Zachary A. Sorrentino 1,2, Grace M. Lloyd ${ }^{1,2}$, Nikolaus R. McFarland 2,3,4, Stefan Prokop 2,3,5 and \\ Benoit I. Giasson ${ }^{1,2,3^{*}}$
}

\begin{abstract}
Multiple system atrophy (MSA) is an insidious middle age-onset neurodegenerative disease that clinically presents with variable degrees of parkinsonism and cerebellar ataxia. The pathological hallmark of MSA is the progressive accumulation of glial cytoplasmic inclusions (GCls) in oligodendrocytes that are comprised of a-synuclein (aSyn) aberrantly polymerized into fibrils. Experimentally, MSA brain samples display a high level of seeding activity to induce further aSyn aggregation by a prion-like conformational mechanism. Paradoxically, aSyn is predominantly a neuronal brain protein, with only marginal levels expressed in normal or diseased oligodendrocytes, and aSyn inclusions in other neurodegenerative diseases, including Parkinson's disease and Dementia with Lewy bodies, are primarily found in neurons. Although GCls are the hallmark of MSA, using a series of new monoclonal antibodies targeting the carboxy-terminal region of aSyn, we demonstrate that neuronal aSyn pathology in MSA patient brains is remarkably abundant in the pontine nuclei and medullary inferior olivary nucleus. This neuronal aSyn pathology has distinct histological properties compared to GCls, which allows it to remain concealed to many routine detection methods associated with altered biochemical properties of the carboxy-terminal domain of aSyn. We propose that these previously underappreciated sources of aberrant aSyn could serve as a pool of aSyn prion seeds that can initiate and continue to drive the pathogenesis of MSA.
\end{abstract}

\section{Introduction}

Multiple system atrophy (MSA) is an adult-onset progressive neurodegenerative disease that clinically presents with variable degrees of parkinsonism, cerebellar ataxia and automatic dysfunction with additional, more variable, neurological symptoms $[1,2]$. MSA can be broadly subtyped into predominant cerebellar-type (MSA-C) or parkinsonian-type (MSA-P) $[1,2]$. The neuropathological hallmark of MSA are glial cytoplasmic inclusions (GCIs) present in oligodendrocytes that were first identified by Gallyas silver staining [3] and later

\footnotetext{
*Correspondence: bgiasson@ufl.edu

1 Department of Neuroscience, College of Medicine, University of Florida, BMS J483/CTRND, 1275 Center Drive, Gainesville, FL 32610, USA

Full list of author information is available at the end of the article
}

shown to be predominantly comprised of the presynaptic neuronal protein $\alpha$-synuclein ( $\alpha$ Syn) $[4,5]$. Although GCIs are reportedly the most abundant type of $\alpha$ Syn pathology in MSA, variable and less abundant neuronal $\alpha$ Syn inclusions have also been described in many brain regions including the putamen, striatum, globus pallidus, substantia nigra, pons, inferior olivary nucleus, hippocampus, cerebellum and various regions of the cerebral cortex [6-16] even in prodromal cases [17].

The progressive accumulation of $\alpha$ Syn pathological inclusions is the hallmark of a spectrum of neurodegenerative disorders termed $\alpha$-synucleinopathies, which include Parkinson's disease and Lewy body dementia (LBD) $[18,19]$. In these latter diseases, and in most other $\alpha$-synucleinopathies, the vast majority of inclusions are original author(s) and the source, provide a link to the Creative Commons licence, and indicate if changes were made. The images or other third party material in this article are included in the article's Creative Commons licence, unless indicated otherwise in a credit line to the material. If material is not included in the article's Creative Commons licence and your intended use is not permitted by statutory regulation or exceeds the permitted use, you will need to obtain permission directly from the copyright holder. To view a copy of this licence, visit http://creativecommons.org/licenses/by/4.0/. The Creative Commons Public Domain Dedication waiver (http://creativeco mmons.org/publicdomain/zero/1.0/) applies to the data made available in this article, unless otherwise stated in a credit line to the data. 
in neurons $[18,19]$, which is congruent with $\alpha$ Syn being predominantly a neuronal brain protein [20-23]. Many in vitro, cellular and animal studies support the notion that $\alpha$ Syn pathology can spread throughout the CNS by a prion-like conformational templating mechanism [19, 24, 25]. However, the source of $\alpha$ Syn in MSA GCIs is still a highly debated conundrum, as it is unclear if $\alpha$ Syn is even expressed in oligodendrocytes [26]. Furthermore, there is little or no increase in $\alpha$ Syn expression in MSA brains compared to control, and it might even be decreased [27-29].

Using a novel series of antibodies targeting the carboxy-terminal region of $\alpha$ Syn, it is demonstrated that $\alpha$ Syn inclusion pathology is very abundant in the pontine nuclei and the inferior olivary nucleus of the medulla oblongata of MSA patients, but these neuronal $\alpha$ Syn inclusions have different histological properties compared to GCIs. We propose that this previously underappreciated, profuse reservoir of neuronal aggregated $\alpha$ Syn, could be a primary source of $\alpha$ Syn prion seeds which convert into a more aggressive GCI strain within oligodendrocytes that thereafter dominates prion-like transmission and progression within these glial cells.

\section{Materials and methods}

\section{Generation of new aSyn monoclonal antibodies}

Synthetic peptides listed in Table 1 corresponding to different amino acid stretches within the carboxyl-terminal region of $\alpha$ Syn were synthesized and purified by GenScript USA, Inc. (Piscataway, NJ). All peptides contained an added Cys residue at the amino-terminus that allowed for conjugation to Imject maleimide-activated mariculture keyhole limpet hemocyanin (mcKLH; Thermo Scientific, Waltham, MA). The peptides conjugated to mcKLH were used to immunize female $B A L B / c$ mice (Jackson Laboratory, Bar Harbor, ME) as previously described [30]. All procedures were performed according to the NIH Guide for the Care and Use of Experimental Animals and were approved by the University of Florida Institutional Animal Care and Use Committee.

Table 1 List of new antibodies described here

\begin{tabular}{llll}
\hline Antibody name & Immunization peptide & asyn residues & Isotype \\
\hline $4 \mathrm{~F} 7$ & CAGPQEGILED & $106-115$ & $\operatorname{lgG} 1$ \\
$2 \mathrm{H} 1$ & CEGILEDMPVD & $110-119$ & $\operatorname{lgG} 1$ \\
$5 \mathrm{H} 12$ & CLEDMPVDPDN & $113-122$ & $\operatorname{lgG} 1$ \\
$4 \mathrm{~F} 11$ & CDMPVDPDNEAY & $115-125$ & $\operatorname{lgG} 1$ \\
$3 \mathrm{~A} 12$ & CPVDPDNEAYEMPS & $117-129$ & $\operatorname{lgG} 1$ \\
\hline
\end{tabular}

Shown are the synthetic peptides used for mouse immunization and their corresponding amino acid residue localization in human aSyn. The isotype of each antibody is included
The spleens from the immunized mice were harvested and the white bloods cells were fused with mouse myeloma (Sp2/O-Ag14; ATCC, Manassas, VA) as previously described [30]. Following selection with HAT supplement (Sigma Aldrich, St. Louis, MO), all hybridoma clones were initially screened for reactivity by enzymelinked immunosorbent assay (ELISA) using the respective peptides used for immunization.

Antibody isotypes were determined using a mouse monoclonal isotyping kit (Millipore Sigma, Burlington, MA).

\section{Enzyme-linked immunosorbent assay (ELISA)}

96-well ELISA plates (Corning Life Sciences, Corning, NY) were coated with $100 \mathrm{ng}$ peptide in $100 \mu \mathrm{L}$ PBS per well using the peptide used for immunization (see Table 1). Wells were washed with PBS and blocked with $\mathrm{PBS} / 5 \%$ fetal bovine serum (FBS). Primary antibodies were added to blocking solution and incubated at room temperature. After PBS washes, plates were incubated with horseradish peroxidase-conjugated anti-mouse antibody (Jackson Immuno Research Labs, West Grove, $\mathrm{PA}$ ) in 5\% FBS/PBS for an hour. Plates were washed with PBS and 3,3',5,5'-tetramethylbenzidine (TMB substrate, Thermo Fisher Scientific, Waltham, MA) was added to each well. The reactions were stopped by adding $0.5 \mathrm{M}$ $\mathrm{HCl}$ and the optical density was measured at $450 \mathrm{~nm}$ with a plate reader.

\section{Immunohistochemistry of human brain tissue}

Formalin-fixed brain samples of patients with LBD, MSA, and controls were provided by the University of Florida Neuromedicine Human Brain and Tissue Bank (UF HBTB) following institutional regulations. Postmortem diagnoses of LBD, MSA, AD neuropathological change, and other changes were made according to current guidelines and criteria proposed by the National Institute of Aging-Alzheimer's Association [31], the Dementia with Lewy Bodies Consortium [32], and the Neuropathology Working Group on MSA [2]. See Table 2 for details on human cases used for this study.

For immunohistochemistry (IHC), paraffin-embedded tissue on slides were rehydrated in xylene and a series of ethanol solutions $(100 \%, 90 \%$, and $70 \%)$. For antigen retrieval, slides were treated with $70 \%$ formic acid for $20 \mathrm{~min}$ at room temperature and after extensive washing placed in a steam bath for $60 \mathrm{~min}$ in a solution of modified citrate buffer (Target Retrieval Solution Citrate $\mathrm{pH}$ 6; Agilent, Santa Clara, CA). Endogenous peroxidases were quenched by submerging slides in PBS solutions with $1.5 \%$ hydrogen peroxide and $0.005 \%$ Triton-X-100. After washing, slides were blocked in $2 \% \mathrm{FBS} / 0.1 \mathrm{M}$ Tris, $\mathrm{pH} 7.6$ and were incubated in primary antibody 
Table 2 Summary of cases used in this study

\begin{tabular}{|c|c|c|c|c|c|c|c|c|}
\hline Case & $\begin{array}{l}\text { Clinical } \\
\text { diagnosis }\end{array}$ & Primary pathological diagnosis & Secondary pathological diagnosis & Thal & Braak & CERAD & Gender & Age \\
\hline Control 1 & Normal & AD low & & 1 & $\|$ & none & M & 88 \\
\hline Control 2 & Normal & PART & & 0 & $\|$ & none & $\mathrm{F}$ & 72 \\
\hline Control 3 & Normal & No significant pathological findings & & 0 & 0 & none & $\mathrm{F}$ & 55 \\
\hline Control 4 & Normal & Remote micro-infarcts and calcifications & & 0 & 0 & none & M & 59 \\
\hline MSA-1 & MSA-C & MSA & & 0 & 0 & none & $\mathrm{F}$ & 67 \\
\hline MSA-2 & MSA-P & MSA & AD intermediate & 1 & III & moderate & M & 71 \\
\hline MSA-3 & MSA-P & MSA & AD low & 1 & 1 & none & $\mathrm{F}$ & 60 \\
\hline MSA-4 & MSA-P & MSA & PART & 0 & $\|$ & none & M & 77 \\
\hline MSA-5 & MSA-C & MSA & AD low; CAA & 3 & । & sparse & M & 71 \\
\hline MSA-6 & MSA-P & MSA & AD low; CAA & 3 & । & sparse & $\mathrm{F}$ & 68 \\
\hline MSA-7 & MSA-C & MSA & AD intermediate & 3 & III & sparse & M & 59 \\
\hline MSA-8 & MSA-P/C & MSA & PART; CAA & 0 & 1 & none & $F$ & 66 \\
\hline MSA-9 & MSA-P & MSA & & 0 & 0 & none & $\mathrm{F}$ & 66 \\
\hline MSA-10 & MSA-P/C & MSA & & 0 & 0 & 0 & M & 53 \\
\hline LBD-1 & DLB & LBD diffuse neocortical & AD intermediate; CAA & 5 & IV & moderate & M & 67 \\
\hline LBD-2 & DLB & LBD diffuse neocortical & AD high; CAA; LATE (stage 1) & 5 & V & frequent & $\mathrm{F}$ & 68 \\
\hline LBD-3 & DLB/AD & LBD diffuse neocortical & AD intermediate; CAA; LATE (stage 2) & 3 & V & frequent & M & 83 \\
\hline LBD-4 & DLB & LBD diffuse neocortical & AD intermediate; CAA; ARTAG & 4 & III & sparse & $\mathrm{F}$ & 67 \\
\hline
\end{tabular}

Listed are the clinical and pathological diagnoses, the sex, age at death and Thal, Braak and CERAD ratings

$A D$ Alzheimer's disease, ARTAG aging related tau astrogliopathy, CAA cerebral amyloid angiopathy, DLB dementia with Lewy body, $L A T E$ limbic-predominant age related TDP-43 encephalopathy, LBD Lewy body disease, MSA-C multiple system atrophy with predominant cerebellar ataxia, $M S A-P$ multiple system atrophy with predominant parkinsonism, $P A R T$ primary age-related tauopathy

overnight at $4{ }^{\circ} \mathrm{C}$. After washes with $0.1 \mathrm{M}$ Tris, $\mathrm{pH} 7.6$, a mixture of biotinylated secondary antibody (Vector Laboratories; Burlingame, CA) and ImmPRESS polymer secondary antibody (Vector Laboratories; Burlingame, CA) were similarly diluted in block solution and applied to sections for $1 \mathrm{~h}$ at room temperature. An avidin-biotin complex $(\mathrm{ABC})$ system (Vectastain $\mathrm{ABC}$ Elite kit; Vector Laboratories, Burlingame, $\mathrm{CA}$ ) was used to enhance detection of the immunocomplexes, which were visualized using the chromogen 3,3'-diaminobenzidine (DAB kit; KPL, Gaithersburg, MD). Tissue sections were counterstained with hematoxylin (Sigma Aldrich, St. Louis, $\mathrm{MO})$. Slides were dehydrated in ethanol solutions $(70 \%$, $90 \%$, and $100 \%$ ) and xylene before they were covered with Cytoseal (Thermo Fisher Scientific, Waltham, MA). Slides were digitally scanned using an Aperio Slide Scanner AT2 instrument (40X magnification; Aperio Technologies Inc., Vista, CA).

Other mouse monoclonal antibodies used for IHC included anti-ubiquitin antibody Ubi-1 (Thermo Fisher Scientific, Waltham, MA), anti-p62/sequestrosome-1 (p62) antibody 5G3 [33], and C-terminal $\alpha$ Syn 94-3A10 specific for residues 130-140 [34].

For double labelling, the procedures were similar, but the steam bath in modified citrate buffer retrieval was performed prior to formic acid treatment. Rabbit anti-neurofilament light chain (NFL) (C28E10; Cell Signaling Technology) or rabbit anti-microtubule-associated protein 2 (MAP2) (4542; Cell Signaling Technology) antibodies were applied overnight with anti- $\alpha$ Syn $5 \mathrm{H} 12$ antibody. After the DAB reaction, the tissue was rinsed and ImmPRESS anti-rabbit conjugated to alkaline phosphatase (Vector Laboratories) was applied for $1 \mathrm{~h}$. After washes, the tissues sections were incubated in $0.1 \mathrm{M}$ Tris, $\mathrm{pH} 8.45$ and labeling was visualized with Vector Red substrate (Vector Laboratories). Tissue sections were dehydrated and mounted as described above but without hematoxylin counterstain.

\section{Gallyas silver staining}

For silver staining, paraffin-embedded tissue on slides were rehydrated in xylene and series of ethanol solutions $(100 \%, 90 \%$, and $70 \%)$ followed by a washes in $\mathrm{dH}_{2} \mathrm{O}$. Sections were incubated in $5 \%$ periodic acid for $5 \mathrm{~min}$, washed twice in $\mathrm{dH}_{2} \mathrm{O}$ for $5 \mathrm{~min}$ and placed in alkaline silver iodide ( $4 \%$ sodium hydroxide, $10 \%$ potassium iodide

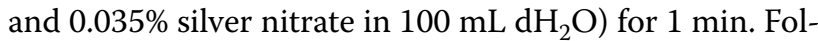
lowing a $10 \mathrm{~min}$ wash step in $0.5 \%$ acetic acid, the sections were placed in developer solution for 5-10 min until desired staining was achieved (Stock solution I: $5 \%$ sodium carbonate in water; Stock solution II: $0.2 \%$ ammonium nitrate, $0.2 \%$ silver nitrate, $1 \%$ tungstosilicic 
acid in water; Stock solution III: $0.2 \%$ ammonium nitrate, $0.2 \%$ silver nitrate, $1 \%$ tungstosilicic acid, $0.73 \%$ formaldehyde in water; 3 volumes of stock solution II added to 10 volumes of stock solution I followed by 7 volumes of stock solution III). Subsequently, sections were washed in $0.5 \%$ acetic acid for 3 min, rinsed in $\mathrm{dH}_{2} \mathrm{O}$ for 5 min and incubated in $0.1 \%$ gold chloride for $5 \mathrm{~min}$. After a $5-\mathrm{min}$ rinse in $\mathrm{dH}_{2} \mathrm{O}$, sections were incubated in $1 \%$ sodium thiosulphate for $5 \mathrm{~min}$ and rinsed in tap water. Sections were counterstained with nuclear fast red (Thermo Fisher Scientific, Waltham, MA) according to manufacturer's instructions. Slides were dehydrated in ethanol solutions (70\%, 90\%, and 100\%) and xylene before they were covered with Cytoseal (Thermo Fisher Scientific, Waltham, MA). Slides were digitally scanned using an Aperio Slide Scanner AT2 instrument (40X magnification; Aperio Technologies Inc., Vista, CA).

\section{Sequential biochemical fractionation of human nervous tissue}

White matter from the cerebellum and pons of MSA (MSA-1, -8, and -9) and control (control-1, -2, and -3) patients were used. Tissues were homogenized with $3 \mathrm{~mL}$ per gram of tissue with high salt (HS) buffer $(50 \mathrm{mM}$ Tris, pH7.5, $750 \mathrm{mM} \mathrm{NaCl}, 20 \mathrm{mM} \mathrm{NaF}, 5 \mathrm{mM}$ EDTA) with a cocktail of protease inhibitors $(1 \mathrm{mM}$ phenylmethylsulfonyl fluoride and $1 \mathrm{mg} / \mathrm{mL}$ each of pepstatin, leupeptin, N-tosyl-L-phenylalanyl chloromethyl ketone, $\mathrm{N}$-tosyl-lysine chloromethyl ketone and soybean trypsin inhibitor). The tissue homogenates then underwent sedimentation at $100,000 \times \mathrm{g}$ for $30 \mathrm{~min}$ and the supernatants were removed and kept as the HS fraction. Pellets were re-extracted in $3 \mathrm{~mL}$ per gram of tissue with HS buffer with $1 \%$ Triton X-100 (HS/T buffer) and centrifuged at $100,000 \times \mathrm{g}$ for $30 \mathrm{~min}$. The supernatants were removed and kept as the HS/T fraction. The pellets were then homogenized in $3 \mathrm{~mL}$ per gram of tissue with HS buffer/1\% Trition X-100 with $1 \mathrm{M}$ sucrose and centrifuged at $100,000 \times \mathrm{g}$ for $30 \mathrm{~min}$ to float the myelin, which was discarded. Pellets were homogenized in $2 \mathrm{~mL}$ per gram of tissue with radioimmunoprecipitation assay (RIPA) buffer (50 mM Tris, pH 8.0, $150 \mathrm{mM} \mathrm{NaCl,} 5 \mathrm{mM}$ EDTA, 1\% NP-40, 0.5\% sodium deoxycholate, $0.1 \%$ SDS) plus protease inhibitors and centrifuged at $100,000 \times \mathrm{g}$ for $30 \mathrm{~min}$. Supernatants were removed and kept as the RIPA fraction. Pellets were then homogenized in $1 \mathrm{~mL}$ per gram of tissue with $2 \% \mathrm{SDS} / 4 \mathrm{M}$ urea by probe sonication, and centrifuged at $100,000 \times \mathrm{g}$ for $30 \mathrm{~min}$ and supernatant was kept as the SDS/U fractions. Protein concentrations of all fractions were determined by BCA assay using bovine serum albumin (BSA; Pierce, Rockford, IL) as a standard. SDS sample buffer was added to the fractions which were incubated for $10 \mathrm{~min}$ at $100{ }^{\circ} \mathrm{C}$
(HS and HS/T fractions) or at room temperature (SDS/U fraction only). Equal amounts of protein $(10 \mu \mathrm{g}$ for each fraction) were resolved by SDS-PAGE and analyzed by immunoblot.

\section{Recombinant synuclein proteins}

Human and mouse $\alpha$ Syn, human $\beta$-synuclein ( $\beta$ Syn), human $\gamma$-synuclein ( $\gamma$ Syn) and 1-129, 1-125, 1-122, 1-119 and 1-115 carboxy-truncated human $\alpha$ Syn were expressed using the bacterial expression plasmid pRK172 in BL21 (DE3) E. coli (New England Biolabs Inc). The proteins were purified using size exclusion chromatography followed by Mono $\mathrm{Q}$ anion exchange chromatography as previously described [35].

\section{Immunoblotting analyses}

Protein samples were resolved by SDS-PAGE on 15\% SDS-polyacrylamide gels. The proteins were then electrophoretically transferred onto $0.2 \mu \mathrm{m}$ pore size nitrocellulose membranes (Bio-Rad, Hercules, CA) in carbonate transfer buffer $\left(10 \mathrm{mM} \mathrm{NaHCO}, 3 \mathrm{mM} \mathrm{Na}_{2} \mathrm{CO}_{3}, \mathrm{pH}\right.$ 9.9) [36] with $20 \%$ methanol with a constant current of $255 \mathrm{~mA}$ for $75 \mathrm{~min}$. Membranes were washed with Trisbuffered saline (TBS), blocked with $5 \%$ milk/TBS and incubated overnight at $4{ }^{\circ} \mathrm{C}$ with primary antibodies. Following washing, blots were incubated with horseradish peroxidase conjugated goat anti-mouse antibody (Jackson Immuno Research Labs, West Grove, PA) diluted in $5 \%$ milk/TBS for $1 \mathrm{~h}$. Following washing, the labeled protein bands were visualized by chemiluminescence using Western Lightning Plus ECL reagents (PerkinElmer Life Sciences, Waltham, MA) and with a GeneGnome XRQ imager (Syngene, Frederick, MD).

\section{Results}

$\alpha$ Syn carboxy-terminal truncation, which occurs due to a spectrum of various biological cleavage events, is the predominant post translational modification associated with the formation of $\alpha$ Syn pathological inclusions [37]. This type of modification can dramatically promote the formation of $\alpha$ Syn pathological inclusions [37]. Aiming at better understanding the relationship between these different modifications of $\alpha$ Syn, and pathological inclusions, we generated a novel series of monoclonal antibodies with epitopes targeting various regions within the carboxy-terminal domain of $\alpha$ Syn. The antibodies used in studies here are summarized in Table 1 and Additional file 1: Fig. S1. Starting with a larger series of antibodies, a subset was identified that revealed extensive abundant, and consistent neuronal pathology in the pontine nuclei across the MSA patient brains used here, as shown in representative images (Fig. 1; Table 2). These antibodies also labeled nigral Lewy bodies, 


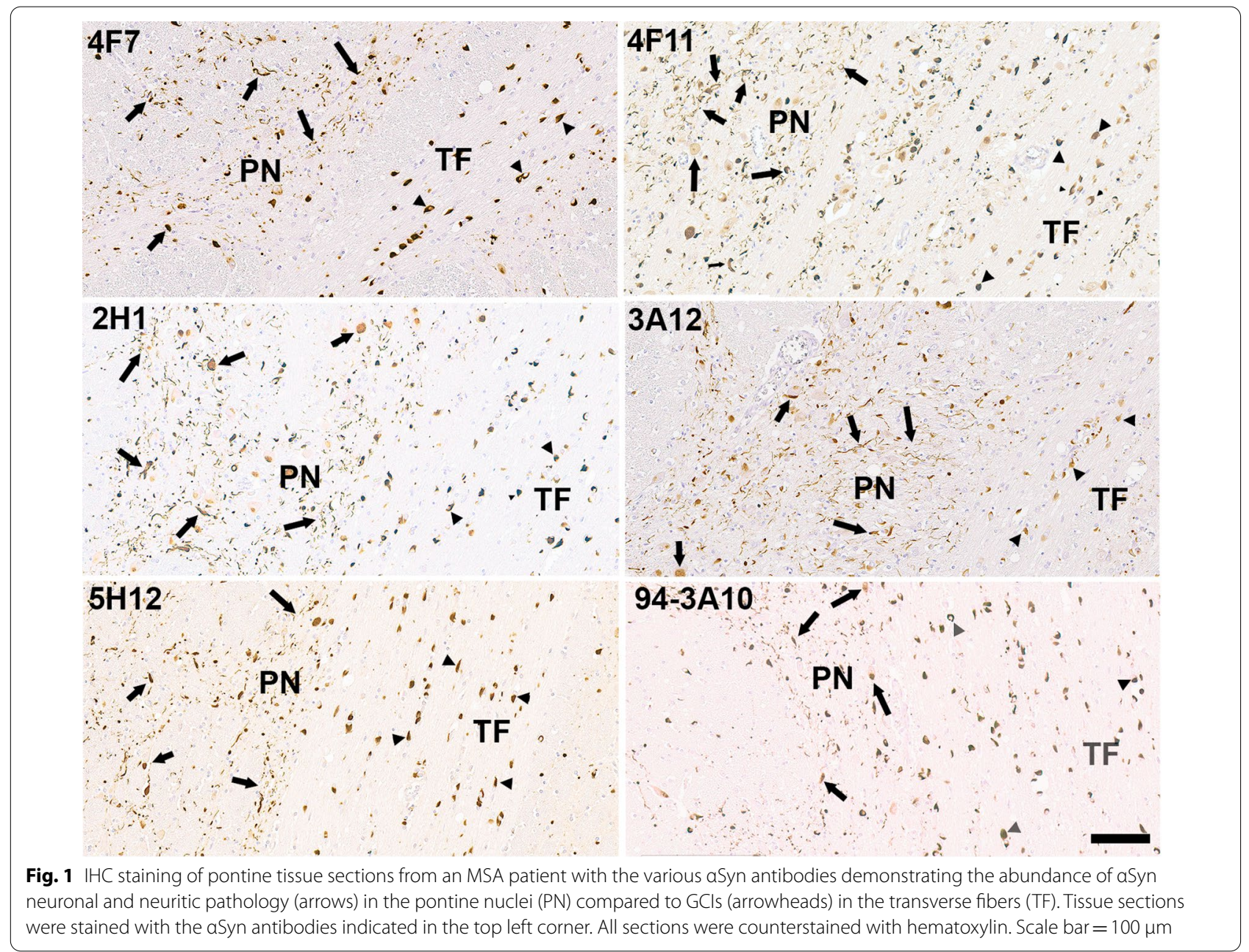

cortical Lewy bodies and Lewy neurites in LBD patients (Additional file 1: Fig. S2) and GCIs in MSA patients (Additional file 1: Fig. S3), but the abundance of inclusions in neuronal cell bodies and surrounding processes in the pontine nuclei revealed by these antibodies was remarkable (Figs. 1, 2). No pathological inclusions were observed in control patients (Additional file 1: Fig. S4; data not shown). The epitopes for these antibodies were further mapped and characterized with recombinant $\alpha$ Syn carboxy-truncated proteins and the related proteins $\beta$ Syn and $\gamma$ Syn (Additional file 1: Fig. S5) with findings summarized in Additional file 1: Fig. S1. Overall, the epitopes for these antibodies spanned different regions on the carboxy-terminal region of $\alpha$ Syn. These antibodies were used to stain various other brain regions of MSA patients including the midbrain, putamen, caudate, globus pallidus, and cerebellum that typically have abundant GCIs and less abundant neuronal $\alpha$ Syn inclusions $[6,7,9]$. Consistent with these previous studies, the predominant forms of $\alpha$ Syn inclusions observed in these regions were GCIs with some sparse neuronal inclusions observed in the midbrain and basal ganglia (Additional file 1: Fig. S3; data not shown).

The neuronal cytoplasmic inclusions observed in MSA pontine nuclei were varied in morphology, ranging from aggregates that filled most of the cytoplasm to more defined skein-like inclusions (Fig. 2a-c). The abundant $\alpha$ Syn accumulations stained within processes in the pontine nuclei were not observed in pontine transverse fibers that were laden with GCIs (Fig. 2d), indicating that immunoreactive processes in pontine nuclei are likely dendrites from the pontine nuclei neurons. Further neuroanatomical investigation for other pathologies with the new $\alpha$ Syn antibodies also uniquely revealed abundant neuroaxonal spheroids within the middle cerebral peduncle (Fig. 2e) that are likely the axonal projections of neurons within the pontine nuclei. In the cerebellar hemispheres only GCIs were labelled within the white matter with some additional, less abundant GCIs interspersed within the granular layer (Fig. 2f). 

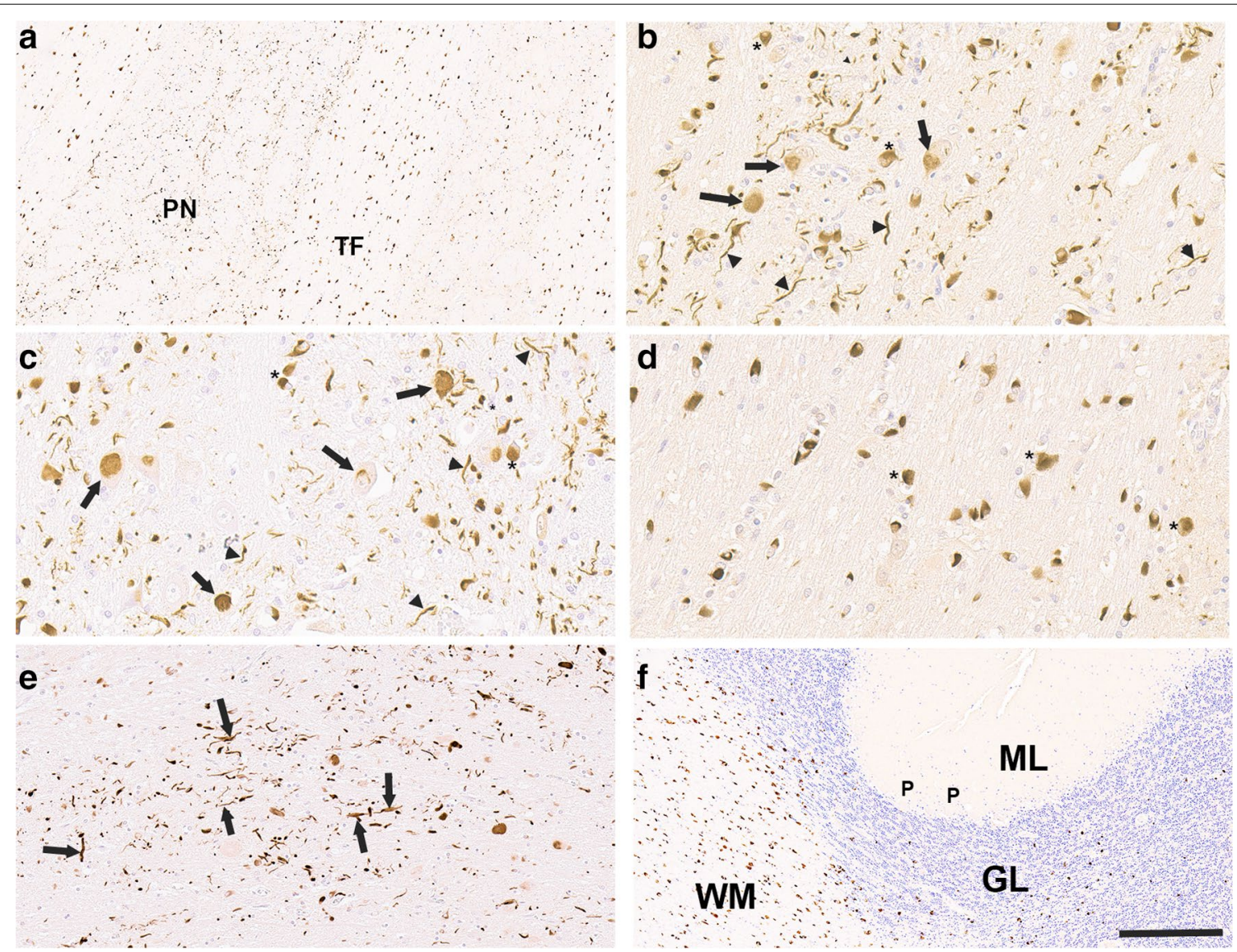

Fig. 2 Abundant neuronal aSyn inclusion pathology in the pontine nuclei of MSA patients. a Low magnification image showing abundant aSyn inclusion pathology in pontine nuclei (PN) and transverse fibers (TF) within the pons with $5 \mathrm{H} 12$ antibody. $\mathbf{b}$, c Higher magnification showing that aSyn pathology with antibodies $5 \mathrm{H} 12$ (b) and $2 \mathrm{H} 1$ (c) in the pontine nuclei is predominantly within neuronal cell bodies (arrows) and processes (arrowheads) with a few GCls (asterisks). $\mathbf{d}$ In the transverse fibers of the pons, aSyn is predominantly in GCls (asterisks) as stained with $5 \mathrm{H} 12$ antibody. (e) Abundant aSyn neuroaxonal pathology (arrows) was also observed in the middle cerebellar peduncle stained with $5 \mathrm{H} 12$ antibody. (f) In the cerebellum, aSyn inclusions are all in the form of GCls predominantly in the white matter (WM), but occasionally within the granular layer (GL) stained with $5 \mathrm{H} 12$ antibody. Neurons of the granular layer and Purkinje neurons (P) at the boundary with the molecular layer (ML) do not have aSyn inclusion. In $\mathbf{a}, \mathbf{b}, \mathbf{d}-\mathbf{f}$ sections were stained with $5 \mathrm{H} 12$ antibody. Antibody $2 \mathrm{H} 1$ was used in $\mathbf{c}$. Sections were counterstained with hematoxylin. Scale bar $=300 \mu \mathrm{m}$ in $\mathbf{a}, \mathbf{f} ; 120 \mu \mathrm{m}$ in $\mathbf{e} ; 60 \mu \mathrm{m}$ in $\mathbf{b}-\mathbf{d}$

Double staining of the pons with anti-MAP2 or antiNFL antibodies as neuronal markers and anti- $\alpha$ Syn $5 \mathrm{H} 12$ antibody, demonstrated that the $\alpha$ Syn inclusions in pontine nuclei are in neurons with GCIs in close proximity, but not labelled with, the neuronal markers (Fig. 3a, b). IHC with anti-ubiquitin and anti-p62 antibodies revealed major differences between the neuronal inclusions and GCIs (Fig. 3c, d). While GCIs are strongly labeled for ubiquitin and p62, the majority of the neuronal inclusions in the pontine nuclei were not reactive or weakly labeled.

In addition to the pontine nuclei, abundant neuronal $\alpha$ Syn inclusion pathology was also observed in the inferior olivary nucleus of the medulla oblongata, and can be readily identified, even at low magnifications (Fig. 4a).
These inclusions were not observed in control cases (Additional file 1: Fig. S4) and filled most of the neuronal cell bodies, with aggregates often in the nucleus (Fig. 4b). The neurites surrounding these neurons also contained extensive $\alpha$ Syn accumulation that can be discerned, even at low magnification (Fig. 4a, b). The neuronal inclusions in the inferior olivary nucleus were double labeled for anti-NFL (Fig. 4c). These neuronal inclusions were modestly labeled for ubiquitin while mostly not reactive for p62 compared to GCIs that were strongly labeled for both ubiquitin and p62 (Fig. 4d, e).

To further characterize the $\alpha$ Syn inclusions present in MSA patients, white matter tissue from the cerebellar hemispheres that predominantly contained GCIs and the pons containing the pontine nuclei with both neuronal 

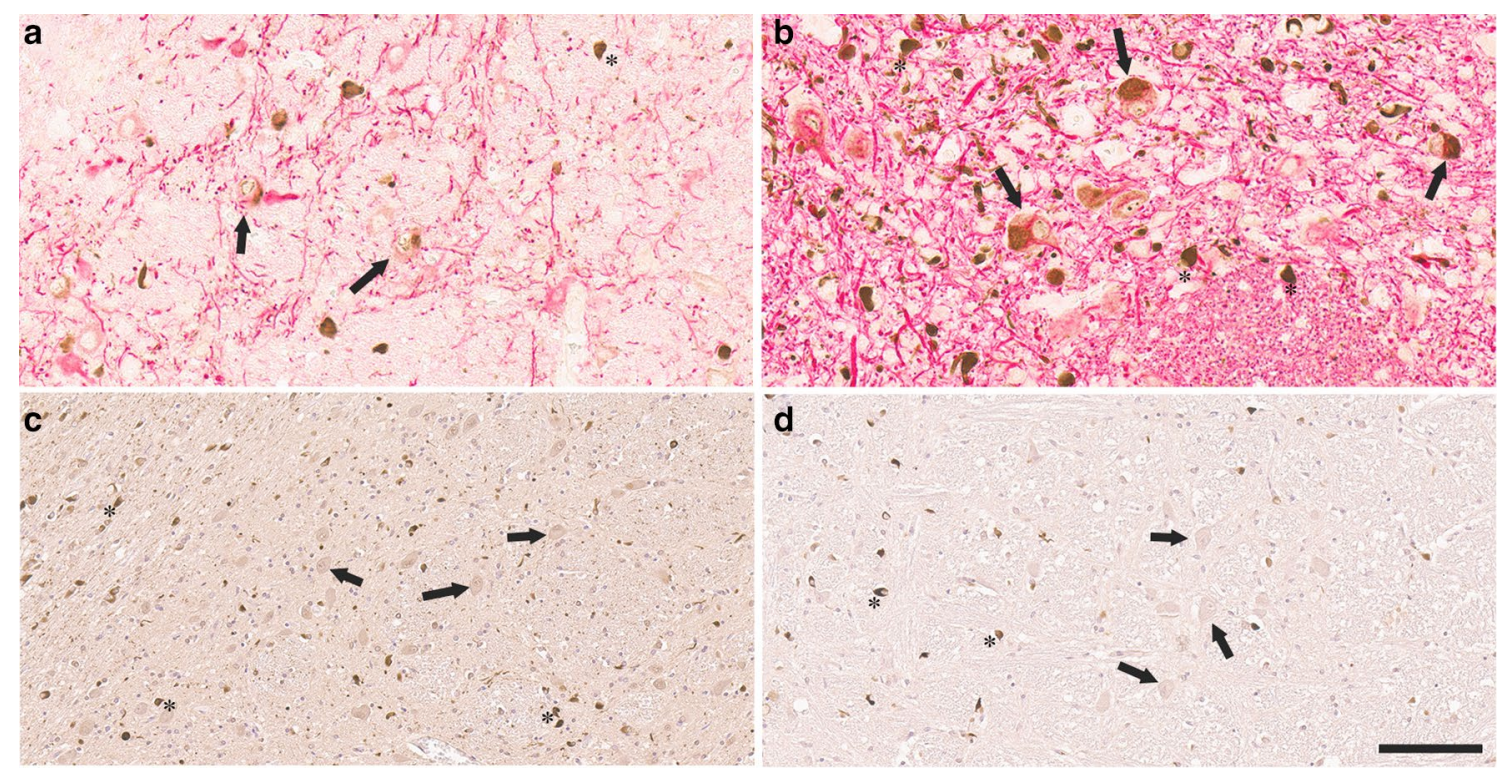

Fig. 3 Characterization of neuronal inclusions in the pontine nuclei of MSA patients. a Double staining of the pons of an MSA patient with anti-MAP2 (red) and anti-aSyn 5H12 (brown) antibodies. b Double staining of the pons of an MSA patient with anti-NFL (red) and anti-aSyn 5H12 (brown) antibodies. $\mathbf{c} I H C$ with anti-ubiquitin antibody Ubi-1. d $I H C$ with anti-p62 antibody 5G3. In $\mathbf{c}$ and $\mathbf{d}$, the tissue sections were also counterstained with hematoxylin. Arrows depict neuronal cell bodies within the pontine nuclei and asterisks highlight GCls. Scale bar $=60 \mu \mathrm{m}$ in $\mathbf{a}$, b and $120 \mu \mathrm{m}$ in $\mathbf{c}, \mathbf{d}$
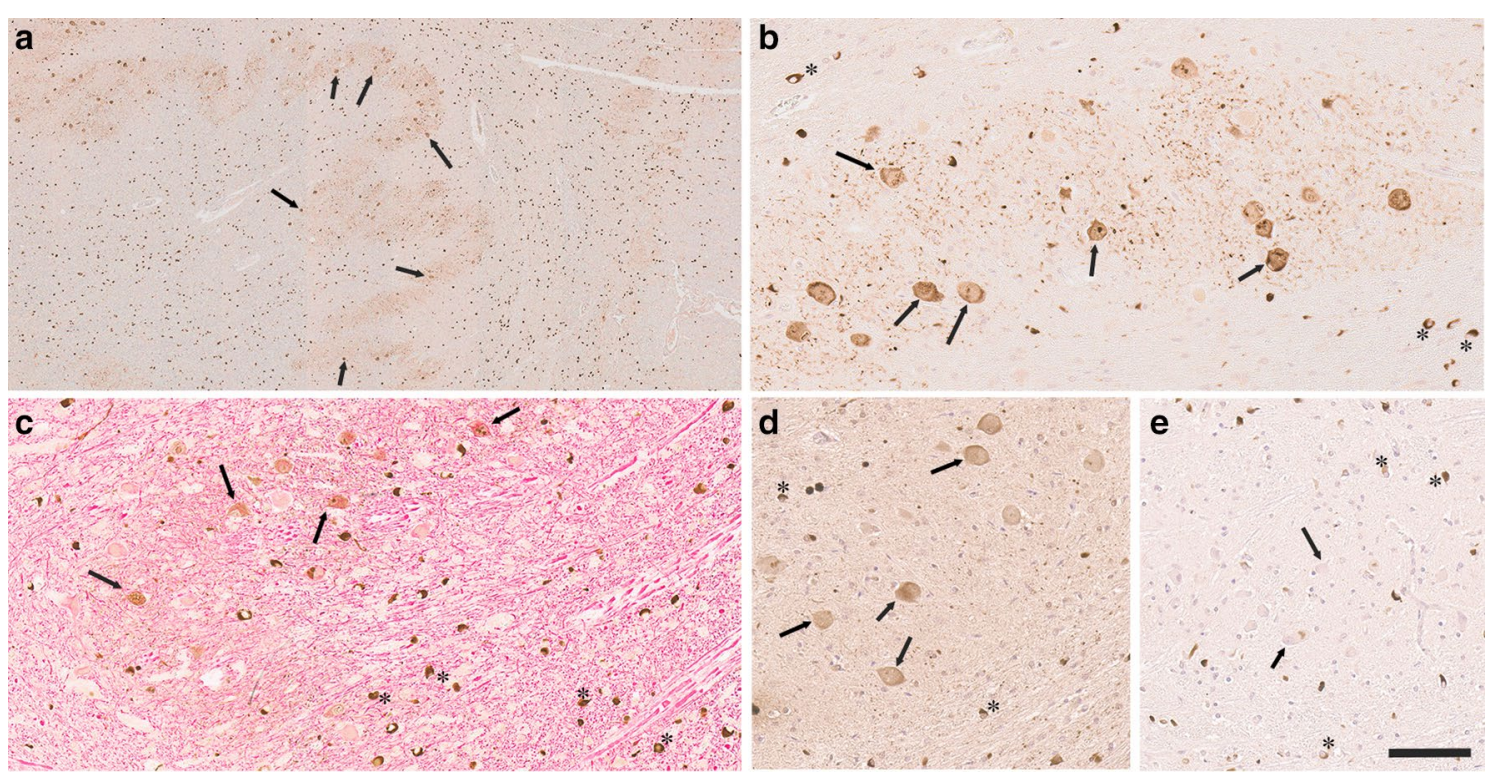

Fig. 4 Abundant neuronal inclusions in the inferior olivary nucleus in MSA patients. $\mathbf{a}$ Low and $\mathbf{b}$ higher magnification images of inferior olivary nucleus region stained with $5 \mathrm{H} 12$ antibody showing abundant aSyn inclusion pathology in the cell bodies and nucleus surrounded by extensive neuritic pathology. c Double labeling with anti-NFL (red) and anti-aSyn $5 \mathrm{H} 12$ (brown) antibodies in the inferior olivary nucleus region. d Perikaryal inclusions within the inferior olivary nucleus are also labeled by anti-ubiquitin staining. e $\mathrm{HC}$ with anti-p62 antibody $5 \mathrm{G} 3$ in the inferior olivary nucleus. In $\mathbf{a}, \mathbf{b}, \mathbf{d}$ and $\mathbf{e}$, the tissue sections were also counterstained with hematoxylin. Scale bar $=500 \mu \mathrm{m}$ in $\mathrm{A} ; 100 \mu \mathrm{m}$ in $\mathbf{b}-\mathbf{e}$. Arrows depict neuronal inclusions within the inferior olivary nucleus and asterisks highlight GCls 
inclusions and GCIs were sequentially biochemically fractionated with solution of increased protein solubility (Additional file 1: Fig. S6) and analyzed by immunoblotting (Fig. 5). The MSA fractions were compared to extracts from control patients with 3 different antibodies:
4F7 (epitope residues 106-115), 5H12 (epitope residues 113-122) and 94-3A10 (epitope residues 130-140). In control patients, $\alpha$ Syn was detected in the HS soluble fractions which was also detected in MSA patients, but with a redistribution into the SDS/U fractions that

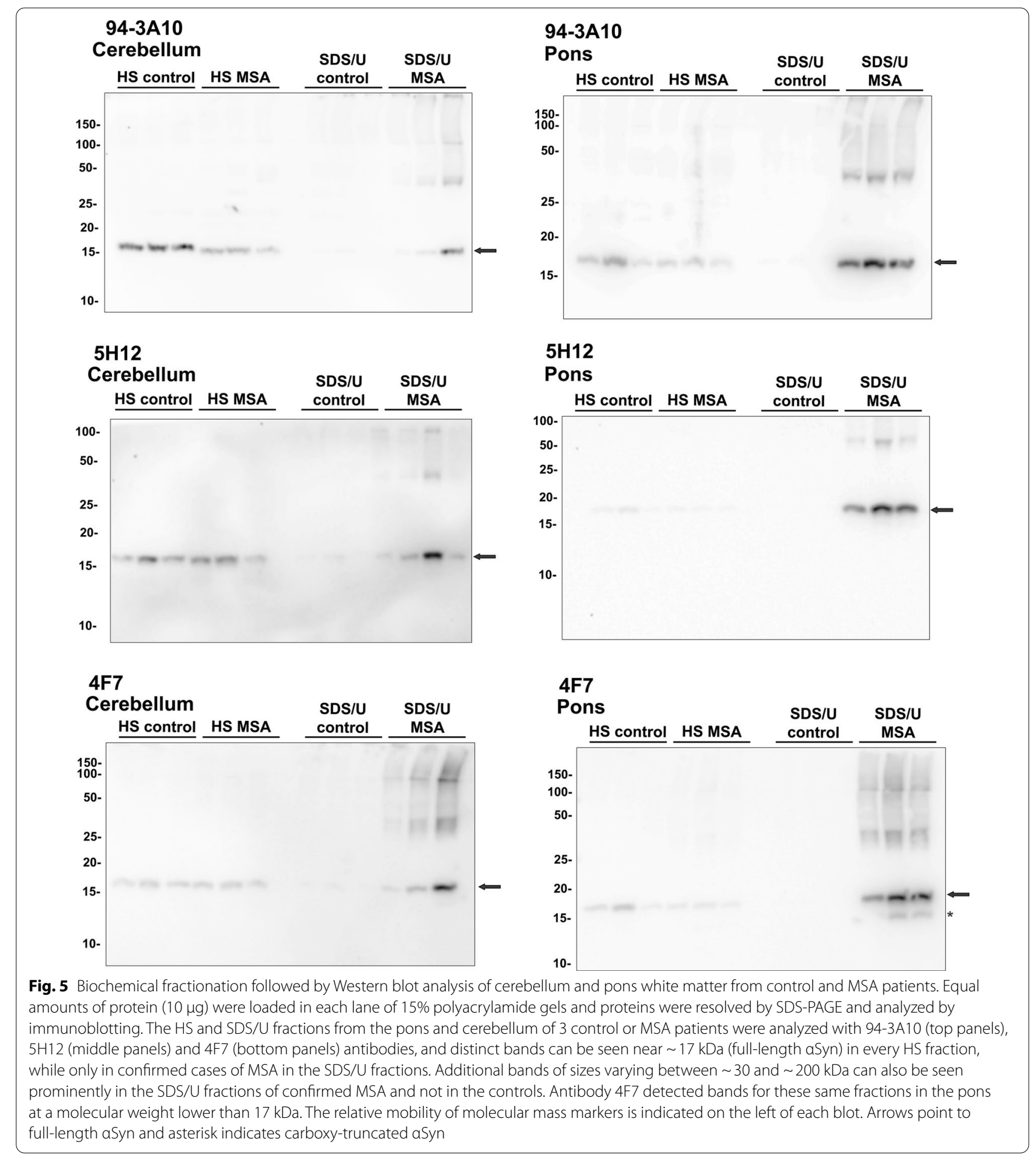


reflects protein aggregation in MSA patients (Fig. 5). $\alpha$ Syn was mostly present at the molecular mass of fulllength protein in the HS soluble fractions in control and MSA fractions for both brain regions. In the SDS/U fractions from the cerebellum of MSA patients, full-length $\alpha$ Syn was detected, as well as higher molecular mass smear that represent modified forms of $\alpha$ Syn, especially with antibody 4F7. In the pons of MSA patients, similar findings were observed, but with additional carboxytruncated $\alpha$ Syn that was detected with antibody $4 \mathrm{~F} 7$ (Fig. 5).

As GCIs were initially discovered using Gallyas silver staining that differentiates them from Lewy pathology [3, 38 ], we compared anti- $\alpha$ Syn $5 \mathrm{H} 12$ staining with Gallyas silver staining. While $5 \mathrm{H} 12$ antibody readily highlighted abundant GCIs, neurites, and neuronal inclusions in the pontine nuclei (Fig. 6a, c) and inferior olivary nucleus (Fig. 6e), Gallyas silver staining predominantly labeled GCIs (Fig. 6b, d, f), while neuronal inclusions only showed occasional faint labeling (Fig. 6d, f, arrowheads) and neurites were largely negative. We also noted that only a subset of GCIs were silver positive, while $5 \mathrm{H} 12$ antibody staining highlighted these inclusions in much higher abundancy (Fig. 6c-f).

\section{Discussion}

Graham and Oppenheimer [39] originally proposed that adult patients with MSA clinical symptoms should be classified as one disorder, but this nosology was not unequivocally established until GCIs were discovered as the hallmark defining inclusion pathology of MSA [3]. These inclusions are predominantly comprised of $\alpha$ Syn
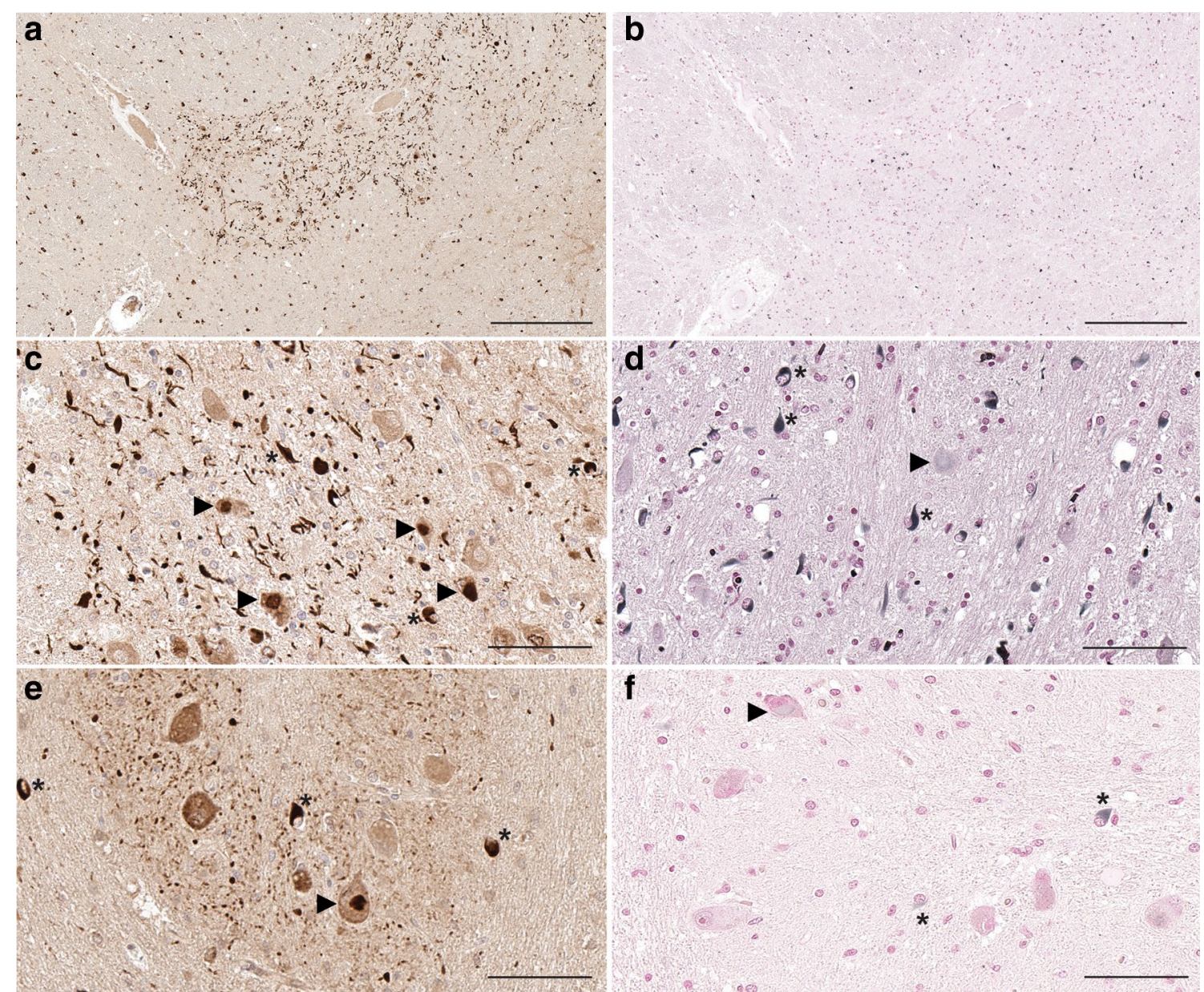

Fig. 6 GCls and brainstem neuronal inclusions are differentially reactive to Gallyas silver staining. a Low magnification images of pontine nuclei demonstrate abundant labeling of $\mathrm{GCls}$, neuritic pathology and neuronal inclusions with $5 \mathrm{H} 12$ antibody, $\mathbf{b}$ while only a subset of GCls and rare neuritic pathology are highlighted by Gallyas silver stain. $\mathbf{c}$, $\mathbf{d}$ High magnification images of pontine nuclei and $\mathbf{e}$, $\mathbf{f}$ inferior olivary nucleus underscore labeling of $\mathrm{GCls}$, neuritic pathology and neuronal inclusions with $5 \mathrm{H} 12$ antibody c, e. Gallyas silver staining only reveals a subset of GCls and rare neuritic pathology in pontine nuclei and neurons of the inferior olive $\mathbf{d}$, f. Rare neuronal inclusions show faint labeling with Gallyas silver staining (arrowheads, d, f). Asterisks highlight GCls. Scale bar: $300 \mu \mathrm{m}$ in $\mathbf{a}$ and $\mathbf{b}, 60 \mu \mathrm{m}$ in c-f 
abnormally polymerized into fibrils $[4,5]$ and a definite diagnosis of MSA still requires a post-mortem assessment for the presence of GCIs $[1,2]$.

MSA is one of many $\alpha$-synucleinopathies where the progressive accumulation of $\alpha$ Syn pathological inclusions in the brain is associated with the insidious nature of these diseases $[18,19]$. A major pathological difference between MSA and other $\alpha$-synucleinopathies is the extensive accumulation of $\alpha$ Syn in oligodendrocytes $[6$, 7, 9-11, 14], while in other neurodegenerative diseases $\alpha$ Syn inclusions are predominantly neuronal $[18,19]$. Since $\alpha$ Syn is an abundant and widely expressed neuronal brain protein [20-23], the presence of neuronal $\alpha$ Syn inclusions is not unexpected, although the specific vulnerability of affected neuronal populations is still not completely explained $[18,19,40]$. Even more enigmatic has been the source of $\alpha$ Syn in MSA GCIs, and the initial driver of $\alpha$ Syn pathology, as oligodendrocytes express marginal levels of $\alpha$ Syn [26].

Many experimental findings have supported the notion that $\alpha$ Syn pathology can spread throughout the CNS by a prion-like conformational templating mechanism $[19,24$, 25]. MSA typically has a more rapid clinical progression than other Lewy body diseases $[1,19,41]$ suggesting a more aggressive spread of pathology by MSA-associated $\alpha$ Syn prions. Congruent with this notion, many experimental findings indicate that GCIs are comprised of polymerized $\alpha$ Syn into distinct prion strains with greater seeding activity compared to preparations derived from neuronal Lewy inclusions. Initial seeding studies in animals and many subsequent investigations using MSA extracts for transmission in mice were performed using M83 A53T $\alpha$ Syn transgenic mice, which are quite permissive to the extensive induction of CNS $\alpha$ Syn pathology, resulting in a lethal motor phenotype following intracellular inoculation compared to other $\alpha$ Syn transgenic models [42-46]. Using the M83 $\alpha$ Syn transgenic mice, CNS $\alpha$ Syn pathology can also be induced by peripheral inoculation with MSA extracts [47]. Thereafter, it was also determined that detergent insoluble MSA extracts, enriched in aggregated $\alpha$ Syn, can also induce $\alpha$ Syn pathology when injected in the brain of wild non-transgenic mice [48, 49]. Using either $\alpha$ Syn transgenic mice or wild type mice, it was shown that aggregated $\alpha$ Syn within lysates from MSA patient brains are significantly more potent at inducing inclusion pathology than similar lysates from Parkinson's disease or LBD patients [43, 4850]; however, the prominent induced form of pathology, when inoculating mice with MSA extracts, is consistently neuronal and not in oligodendrocytes [42-44, 48-50]. The specific induction of $\alpha$ Syn pathology in oligodendrocytes was only observed in mice that transgenically overexpress human $\alpha$ Syn in oligodendrocytes in a mouse $\alpha$ Syn null background [48]. Using $\alpha$ Syn seeds comprised of recombinant $\alpha$ Syn proteins to induce brain pathology in wild type mice can result in some rare inclusions in oligodendrocytes but these are much less abundant than the induced neuronal pathology and they take much longer time to accumulate [51]. The greater potency of the MSA $\alpha$ Syn prion strain compared to Lewy type in Parkinson's disease or LBD also has been observed in cultured cells seeding studies [43, 48, 52, 53].

We report here at least 2 major neuronal populations affected in MSA-the pontine nuclei and inferior olivary nucleus, which contain much more neuronal $\alpha$ Syn pathology than previously appreciated-although neuronal $\alpha$ Syn inclusions have been observed to varying degrees within various brain regions in previous studies $[6-16,54]$. This abundant neuronal $\alpha$ Syn inclusion pathology in MSA was revealed using a new series of $\alpha$ Syn antibodies targeting the carboxy-terminus of $\alpha$ Syn. It was previously demonstrated that staining of GCIs versus Lewy bodies, and even labeling within a given population of GCIs with different $\alpha$ Syn antibodies, can be variable, consistent with the presence of different conformers of polymerized $\alpha$ Syn, akin to different prion-like strains with different degrees of epitope presentation $[9$, $11,48,54]$. These previous studies align with the notion that the new $\alpha$ Syn antibodies described are more effective at detecting $\alpha$ Syn strains that were concealed in these neuronal populations affected by MSA. Recent detailed cyro-EM molecular analysis of MSA $\alpha$ Syn fibrils clearly demonstrated that these have different structures than those from LBD or those assembled from recombinant proteins [55]. Even within MSA $\alpha$ Syn fibrils, many different conformers exist [55] suggesting the likelihood of completely independent and diverse $\alpha$ Syn prion strains or related sub-strains within a given brain. The new antibodies described here are likely more sensitive in revealing some of these subpopulations of aggregated $\alpha$ Syn with conformations that might mask some epitopes.

The extensive neuronal $\alpha$ Syn inclusions in MSA pontine nuclei and inferior olivary nucleus have distinct properties compared to GCIs. They are only weakly reactive to ubiquitin and p62 IHC, as well as Gallyas silver staining compared to GCIs. Our biochemical analyses of MSA brain tissue followed by immunoblotting revealed the presence of aggregated $\alpha$ Syn in both the cerebellar white matter, which contains predominantly GCIs, and the pons, but these presented region differentiating signatures. In the pons, there is a clear accumulation of $\alpha$ Syn carboxy-truncated between residues 115 and 122 . Although at this time we cannot determine if these are specifically associated with the neuronal inclusions in the pons, we are currently characterizing novel antibodies 
specific for carboxy-truncated forms of $\alpha$ Syn to address this issue in future studies.

Given that the pathophysiology underlying the formation of GCIs in MSA is still enigmatic, as oligodendrocytes express marginal levels of $\alpha$ Syn, we propose that the neuronal $\alpha$ Syn inclusion pathology revealed here could be a major contributor to GCI formation. Oligodendrocytes clearly have the ability to take up various forms of $\alpha$ Syn [56]. Besides the neuronal populations identified here, additional neuronal populations with copious amount of aggregated $\alpha$ Syn, potentially produce seeds that are preferentially taken up by oligodendrocytes and are altered into strains with high affinity for oligodendrocytes. Some experimental modeling studies in mice and in cultured cells implicate that the intracellular environmental milieu of the oligodendrocytes is a driving factor in producing a GCI-specific $\alpha$ Syn prion strain(s) which has higher infectivity [48]. Nevertheless, in these studies $\alpha$ Syn strains generated in oligodendrocytes did not present cell type-specific infectivity, although the intrinsic greater infectivity generated the oligodendrocyte environment could be passaged [48]. However, these studies were performed using murine cells and it is possible that oligodendrocyte-specific $\alpha$ Syn prion strains are generated in a human cellular environment. This type of oligodendrocyte-mediated strain would acquire the properties of GCIs in terms of ubiquitin, p62 and Gallyas silver reactivity. The notion that human MSA GCI-type $\alpha$ Syn strains are selectively generated in a human cellular environment would be consistent with the findings that MSA transmission seeding studies in mice did not induce pathology that was Gallyas silver reactive $[42,50]$, although the induced pathology was also predominantly neuronal.

Furthermore, as GCI burden correlates with degeneration of some neuronal populations $[57,58]$, it is possible that $\alpha$ Syn GCI-type prion strains were also taken up by some neuronal populations, but that these are particularly toxic to some neurons, such that $\alpha$ Syn neuronal inclusions that might have existed during the course of the disease are not observed at end stage. This hypothesis would imply that the neurons in the pontine nuclei and inferior olivary nucleus might be more resistant to such strains of misfolded $\alpha$ Syn and that these neurons therefore may also act as a more permanent reservoir of seeds.

Most of the MSA tissues used for the reported seeding studies were from basal ganglia, midbrain, and cerebellum regions that contained predominantly GCIs and only sparse neuronal $\alpha$ Syn inclusions [42-47, 49, 50]. We are not aware of any seeding studies that used medulla that would comprise the abundant neuronal inclusions described here, but a limited number of experiments have used pontine tissue [43] that might have contained the neuronal inclusions underscored here. Future studies should take advantage of the new antibodies described here to re-examine the abundance of neuronal $\alpha$ Syn inclusions in human tissue used for transmission studies and to design seeding studies from MSA brain regions that contain abundant neuronal inclusions compared to almost exclusively GCIs; acknowledging that comparative studies of tissues with only one type of inclusion will be very difficult, as GCIs are interspersed in close proximity of the neuronal inclusions in the pontine nuclei and inferior olivary nucleus.

\section{Conclusions}

Taking advantage of a novel series of $\alpha$ Syn antibodies targeting the carboxy-terminal region, our studies underscore the abundance of $\alpha$ Syn inclusion pathology in the pontine nuclei and inferior olivary nucleus of MSA patients. These neuronal $\alpha$ Syn inclusions are characterized by distinct histological properties relative to GCIs. It is possible that this abundant reservoir of aberrant $\alpha$ Syn could be a primary source of $\alpha$ Syn prion seeds that drives MSA pathobiology, but this notion will have to be further experimentally investigated in future studies.

\begin{abstract}
Abbreviations
aSyn: a-Synuclein; $\beta$ Syn: $\beta$-Synuclein; BSA: Bovine serum albumin; DAB: 3,3'-Diaminobenzidine; ELISA: Enzyme-linked immunosorbent assay; FBS: Fetal bovine serum; $\gamma$ Syn: $\gamma$-Synuclein; GCl: Glial cytoplasmic inclusion; HS: High salt; HS/T: High salt/Triton X-100; IHC: Immunohistochemistry; LBD: Lewy body dementia; MAP2: Microtubule-associated protein 2; mCKLH: Mariculture keyhole limpet hemocyanin; MSA: Multiple system atrophy; MSA-C: Multiple system atrophy predominant cerebellar-type; MSA-P: Multiple system atrophy predominant parkinsonian-type; NFL: Neurofilament light chain; p62: P62/ sequestrosome-1; RIPA: Radioimmunoprecipitation assay; SDS/U: SDS urea; TBS: Tris-buffered saline.
\end{abstract}

\section{Supplementary Information}

The online version contains supplementary material available at https://doi. org/10.1186/s40478-021-01173-y.

Additional file 1: Supplementary Fig. 1. Location of the epitopes for the new aSyn antibodies. The amino acid sequences of human and mouse aSyn, as well as human $\gamma$ Syn and human $\beta$ syn, are shown with points of non-homology to human aSyn highlighted. The three regions of aSyn (N-terminus, NAC region and C-terminus) are labeled and displayed above the sequences. The epitopes of the five novel C-terminal aSyn antibodies were determined based on the peptide used for immunization and immunoblot analysis using carboxy--truncated recombinant aSyn protein (see Additional file 1: Supplemental Fig. 5). Supplementary Fig. 2. $1 \mathrm{HC}$ staining of tissue sections from LBD patients in the substantia nigra, cingulate cortex and amygdala with the various aSyn antibodies labeling Lewy bodies and Lewy neurites. Tissue sections were stained with the aSyn antibodies indicated in the top of each column. All sections were counterstained with hematoxylin. Scale bar $=100 \mu \mathrm{m}$. Supplementary Fig. 3 . IHC staining of cerebellum tissue sections from an MSA patient with the various aSyn antibodies labeling GCls. Tissue sections were stained with the aSyn antibodies indicated in the top left corner. All sections were counterstained with hematoxylin. Scale bar $=100 \mu \mathrm{m}$. Supplementary Fig. 4. $\mathrm{IHC}$ staining with aSyn antibody $5 \mathrm{H} 12$ in a control patient. Tissue 
sections from $\mathbf{a}$ the cerebellum, $\mathbf{b}$ pons and $\mathbf{c}$ medulla oblongata showing the paucity of pathological inclusions. Sections were counterstained with hematoxylin. Scale bar $=300 \mu \mathrm{m}$. Supplementary Fig. 5. Western blot analysis to refine the epitope map and characterize the specificity of the new aSyn antibodies. Immunoblot analysis using recombinant human үSyn, human $\beta$ Syn, mouse (m) aSyn, human (h) aSyn and a series of carboxy-truncated human aSyn (1-129, 1-125, 1-122, 1-119 and 1-115) proteins. $210 \mathrm{ng}$ of each protein was loaded per lane and membranes were probed with the antibodies labeled above. The relative mobility of molecular mass markers is indicated on the left of each blot. Supplementary Fig. 6. Schematic for biochemical fractionation of human brain tissue. Horizontal arrows indicate the solutions added to either the homogenized tissue or pellet resulting from the previous step. From top to bottom, the collected fractions were high salt, HS/Triton X-100 fraction radioimmunoprecipitation assay (RIPA) and SDS/urea fractions. (PDF $11290 \mathrm{~kb}$ )

\section{Acknowledgements}

We thank Jennifer Phillips for excellent technical assistance.

\section{Authors' contributions}

EWH, ZAS, SP, and BIG designed the experiments. EWH, ZAS, GML and BIG performed the experiments. EWH, ZAS, GML, SP and BIG analyzed the data. NRM and SP provide clinical data and key experimental materials. EWH, ZAS, SP, and BIG wrote the manuscript. All authors read and approved the final manuscript.

\section{Funding}

This work was supported by grants from the National Institute on Aging (P30AG066506, P50AG047266) and the National Institute of Neurological Disorders and Stroke (R01NS089022, R01NS100876). NRM is supported by the Wright/Falls/Simmons Professorship in PSP/Atypical Parkinson's. ZAS is supported by fellowship F30AG063446 from the National Institute on Aging.

\section{Availability of data and materials}

All data generated or analyzed during this study are included in this published article and its supplementary information files.

\section{Declarations}

\section{Ethics approval and consent to participate}

Staining of post mortem human tissue samples was performed with approval of the University of Florida institutional review board.

\section{Consent for publication}

Informed consent was obtained according to guidelines of the University of Florida institutional review board.

\section{Competing interests}

The authors declare that they have no competing interests.

\section{Author details}

'Department of Neuroscience, College of Medicine, University of Florida, BMS J483/CTRND, 1275 Center Drive, Gainesville, FL 32610, USA. ${ }^{2}$ Center for Translational Research in Neurodegenerative Disease, College of Medicine, University of Florida, Gainesville, FL 32610, USA. ${ }^{3}$ McKnight Brain Institute, College of Medicine, University of Florida, Gainesville, FL 32610, USA. ${ }^{4}$ Department of Neurology, College of Medicine, University of Florida, Gainesville, FL 32610, USA. ${ }^{5}$ Department of Pathology, College of Medicine, University of Florida, Gainesville, FL 32610, USA.

Received: 25 March 2021 Accepted: 28 March 2021

Published online: 03 May 2021

\section{References}

1. Fanciulli A, Wenning GK (2015) Multiple-system atrophy. New Eng J Med 372:249-263. https://doi.org/10.1056/NEJMra1311488
2. Gilman S, Wenning GK, Low PA, Brooks DJ, Mathias CJ, Trojanowski JQ, Wood NW, Colosimo C, Durr A, Fowler CJ et al (2008) Second consensus statement on the diagnosis of multiple system atrophy. Neurology 71:670-676. https://doi.org/10.1212/01.wnl.0000324625.00404.15

3. Papp MI, Kahn JE, Lantos PL (1989) Glial cytoplasmic inclusions in the CNS of patients with multiple system atrophy (striatonigral degeneration, olivopontocerebellar atrophy and Shy-Drager syndrome). J Neurol Sci 94:79-100

4. Spillantini MG, Crowther RA, Jakes R, Cairns NJ, Lantos PL, Goedert M (1998) Filamentous alpha-synuclein inclusions link multiple system atrophy with Parkinson's disease and dementia with Lewy bodies. Neurosci Lett 251:205-208

5. Tu PH, Galvin JE, Baba M, Giasson B, Tomita T, Leight S, Nakajo S, I watsubo T, Trojanowski JQ, Lee VM-Y (1998) Glial cytoplasmic inclusions in white matter oligodendrocytes of multiple system atrophy brains contain insoluble alpha-synuclein. Ann Neurol 44:415-422

6. Arima K, Ueda K, Sunohara N, Arakawa K, Hirai S, Nakamura M, TonozukaUehara H, Kawai M (1998) NACP/alpha-synuclein immunoreactivity in fibrillary components of neuronal and oligodendroglial cytoplasmic inclusions in the pontine nuclei in multiple system atrophy. Acta Neuropathol (Berl) 96:439-444

7. Armstrong RA, Cairns NJ, Lantos PL (2004) A quantitative study of the pathological changes in ten patients with multiple system atrophy (MSA) J Neural Transm 111:485-495. https://doi.org/10.1007/s00702-003-0105-8

8. Braak H, Rub U, Del Tredici K (2003) Involvement of precerebellar nuclei in multiple system atrophy. Neuropath Appl Neurobiol 29:60-76. https:// doi.org/10.1046/j.1365-2990.2003.00432.x

9. Brettschneider J, Irwin DJ, Boluda S, Byrne MD, Fang L, Lee EB, Robinson $J \mathrm{~L}$, Suh E, Van Deerlin VM, Toledo JB et al (2017) Progression of alphasynuclein pathology in multiple system atrophy of the cerebellar type. Neuropathol Appl Neurobiol 43:315-329. https://doi.org/10.1111/nan. 12362

10. Cykowski MD, Coon EA, Powell SZ, Jenkins SM, Benarroch EE, Low PA, Schmeichel AM, Parisi JE (2015) Expanding the spectrum of neuronal pathology in multiple system atrophy. Brain 138:2293-2309. https://doi. org/10.1093/brain/awv114

11. Duda JE, Giasson BI, Gur TL, Montine TJ, Robertson D, Biaggioni I, Hurtig HI, Stern MB, Gollomp SM, Grossman M et al (2000) Immunohistochemical and biochemical studies demonstrate a distinct profile of alpha-synuclein permutations in multiple system atrophy. J Neuropathol Exp Neurol 59:830-841

12. Lin WL, DeLucia MW, Dickson DW (2004) Alpha-synuclein immunoreactivity in neuronal nuclear inclusions and neurites in multiple system atrophy. Neurosci Lett 354:99-102. https://doi.org/10.1016/j.neulet.2003. 09.075

13. Nishie M, Mori F, Fujiwara $\mathrm{H}$, Hasegawa M, Yoshimoto M, Iwatsubo T, Takahashi H, Wakabayashi K (2004) Accumulation of phosphorylated alpha-synuclein in the brain and peripheral ganglia of patients with multiple system atrophy. Acta Neuropathol 107:292-298. https://doi.org/ 10.1007/s00401-003-0811-1

14. Nishie M, Mori F, Yoshimoto M, Takahashi H, Wakabayashi K (2004) A quantitative investigation of neuronal cytoplasmic and intranuclear inclusions in the pontine and inferior olivary nuclei in multiple system atrophy. Neuropathol Appl Neurobiol 30:546-554. https://doi.org/10.1111/j.13652990.2004.00564.x

15. Yokoyama T, Kusunoki Jl, Hasegawa K, Sakai H, Yagishita S (2001) Distribution and dynamic process of neuronal cytoplasmic inclusion ( $\mathrm{NCl}$ ) in MSA: correlation of the density of $\mathrm{NCl}$ and the degree of involvement of the pontine nuclei. Neuropathology 21:145-154. https://doi.org/10. 1046/j.1440-1789.2001.00390.x

16. Yoshida M (2007) Multiple system atrophy: al pha-synuclein and neuronal degeneration. Neuropathology 27:484-493. https://doi.org/10.1111/j. 1440-1789.2007.00841.x

17. Fujishiro H, Ahn TB, Frigerio R, DelleDonne A, Josephs KA, Parisi JE, Eric Ahlskog J, Dickson DW (2008) Glial cytoplasmic inclusions in neurologically normal elderly: prodromal multiple system atrophy? Acta Neuropathol 116:269-275. https://doi.org/10.1007/s00401-008-0398-7

18. Goedert M (2001) Alpha-synuclein and neurodegenerative diseases. Nat Rev Neurosci 2:492-501 
19. Uchihara T, Giasson BI (2015) Propagation of alpha-synuclein pathology: hypotheses, discoveries, and yet unresolved questions from experimental and human brain studies. Acta Neuropathol 131:49-73. https://doi.org/ 10.1007/s00401-015-1485-1

20. George JM, Jin H, Woods WS, Clayton DF (1995) Characterization of a novel protein regulated during the critical period for song learning in the zebra finch. Neuron 15:361-372

21. Iwai A, Masliah E, Yoshimoto M, Ge N, Flanagan L, de Silva HA, Kittel A, Saitoh T (1995) The precursor protein of non-A beta component of Alzheimer's disease amyloid is a presynaptic protein of the central nervous system. Neuron 14:467-475

22. Jakes R, Spillantini MG, Goedert M (1994) Identification of two distinct synucleins from human brain. FEBS Lett 345:27-32

23. Maroteaux L, Campanelli JT, Scheller RH (1988) Synuclein: a neuronspecific protein localized to the nucleus and presynaptic nerve terminal. J Neurosci 8:2804-2815

24. Brundin P, Melki R (2017) Prying into the prion hypothesis for Parkinson's disease. J Neurosci 37:9808-9818. https://doi.org/10.1523/JNEUROSCl. 1788-16.2017

25. Holec SAM, Woerman AL (2020) Evidence of distinct alpha-synuclein strains underlying disease heterogeneity. Acta Neuropathol. https://doi. org/10.1007/s00401-020-02163-5

26. Miller DW, Johnson JM, Solano SM, Hollingsworth ZR, Standaert DG, Young AB (2005) Absence of alpha-synuclein mRNA expression in normal and multiple system atrophy oligodendroglia. J Neural Transm 112:1613-1624. https://doi.org/10.1007/s00702-005-0378-1

27. Asi YT, Simpson JE, Heath PR, Wharton SB, Lees AJ, Revesz T, Houlden H, Holton JL (2014) Alpha-synuclein mRNA expression in oligodendrocytes in MSA. Glia 62:964-970. https://doi.org/10.1002/glia.22653

28. Langerveld AJ, Mihalko D, DeLong C, Walburn J, Ide CF (2007) Gene expression changes in postmortem tissue from the rostral pons of multiple system atrophy patients. Mov Disord 22:766-777. https://doi.org/10. 1002/mds.21259

29. Ozawa T, Okuizumi K, Keuchi T, Wakabayashi K, Takahashi H, Tsuji S (2001) Analysis of the expression level of alpha-synuclein mRNA using postmortem brain samples from pathologically confirmed cases of multiple system atrophy. Acta Neuropathol (Berl) 102:188-190

30. Rutherford NJ, Brooks M, Giasson BI (2016) Novel antibodies to phosphorylated alpha-synuclein serine 129 and NFL serine 473 demonstrate the close molecular homology of these epitopes. Acta Neuropathol Commun 4:80. https://doi.org/10.1186/s40478-016-0357-9

31. Hyman BT, Phelps CH, Beach TG, Bigio EH, Cairns NJ, Carrillo MC, Dickson DW, Duyckaerts C, Frosch MP, Masliah E et al (2012) National Institute on Aging-Alzheimer's Association guidelines for the neuropathologic assessment of Alzheimer's disease. Alzheimers Dement 8:1-13. https://doi.org/ 10.1016/j.jalz.2011.10.007

32. McKeith IG, Boeve BF, Dickson DW, Halliday G, Taylor JP, Weintraub D, Aarsland D, Galvin J, Attems J, Ballard CG et al (2017) Diagnosis and management of dementia with Lewy bodies: fourth consensus report of the DLB Consortium. Neurology 89:88-100. https://doi.org/10.1212/WNL. 0000000000004058

33. Trejo-Lopez JA, Sorrentino ZA, Riffe CJ, Prokop S, Dickson DW, Yachnis AT, Giasson BI (2020) Generation and characterization of novel monoclonal antibodies targeting p62/sequestosome-1 across human neurodegenerative diseases. J Neuropathol Exp Neurol 79:407-418. https://doi.org/ 10.1093/jnen/nlaa007

34. Dhillon JS, Riffe C, Moore BD, Ran Y, Chakrabarty P, Golde TE, Giasson BI (2017) A novel panel of alpha-synuclein antibodies reveal distinctive staining profiles in synucleinopathies. PLoS ONE 12:e0184731. https://doi. org/10.1371/journal.pone.0184731

35. Sorrentino ZA, Vijayaraghavan N, Gorion KM, Riffe CJ, Strang KH, Caldwell J, Giasson BI (2018) Physiological carboxy-truncation of alpha-synuclein potentiates the prion-like formation of pathological inclusions. J Biol Chem 293:18914-18932. https://doi.org/10.1074/jbc.RA118.005603

36. Dunn SD (1986) Effects of the modification of transfer buffer composition and the renaturation of proteins in gels on the recognition of proteins on Western blots by monoclonal antibodies. Anal Biochem 157:144-153. https://doi.org/10.1016/0003-2697(86)90207-1

37. Sorrentino ZA, Giasson BI (2020) The emerging role of alpha-synuclein truncation in aggregation and disease. J Biol Chem 295:10224-10244. https://doi.org/10.1074/jbc.REV120.011743
38. Uchihara T, Nakamura A, Mochizuki Y, Hayashi M, Orimo S, Isozaki E, Mizutani T (2005) Silver stainings distinguish Lewy bodies and glial cytoplasmic inclusions: comparison between Gallyas-Braak and Campbell-Switzer methods. Acta Neuropathol 110:255-260. https://doi.org/10.1007/ s00401-005-1044-2

39. Graham JG, Oppenheimer DR (1969) Orthostatic hypertension and nicotine insensitivity in a case of mutliple system atrophy. J Neurol Neurosurg Psychiatry 32:28-34

40. Surmeier DJ, Obeso JA, Halliday GM (2017) Selective neuronal vulnerability in Parkinson disease. Nat Rev Neurosci 18:101-113. https://doi.org/10. 1038/nrn.2016.178

41. Krismer F, Wenning GK (2017) Multiple system atrophy: insights into a rare and debilitating movement disorder. Nat Rev Neurol 13:232-243. https:// doi.org/10.1038/nrneurol.2017.26

42. Dhillon JS, Trejo-Lopez JA, Riffe C, Levites Y, Sacino AN, Borchelt DR, Yachnis AY, Giasson BI (2019) Comparative analyses of the in vivo induction and transmission of alpha-synuclein pathology in transgenic mice by MSA brain lysate and recombinant alpha-synuclein fibrils. Acta Neuropathol Commun 7:80. https://doi.org/10.1186/s40478-019-0733-3

43. Prusiner SB, Woerman AL, Mordes DA, Watts JC, Rampersaud R, Berry DB, Patel S, Oehler A, Lowe JK, Kravitz SN et al (2015) Evidence for alpha-synuclein prions causing multiple system atrophy in humans with parkinsonism. Proc Natl Acad Sci U S A 112:E5308-E5317. https://doi.org/10.1073/ pnas. 1514475112

44. Watts JC, Giles K, Oehler A, Middleton L, Dexter DT, Gentleman SM, DeArmond SJ, Prusiner SB (2013) Transmission of multiple system atrophy prions to transgenic mice. Proc Natl Acad Sci USA 110:19555-19560. https://doi.org/10.1073/pnas.1318268110

45. Woerman AL, Oehler A, Kazmi SA, Lee J, Halliday GM, Middleton LT, Gentleman SM, Mordes DA, Spina S, Grinberg LT et al (2019) Multiple system atrophy prions retain strain specificity after serial propagation in two different $\operatorname{Tg}\left(\mathrm{SNCA}^{*}\right.$ A53T) mouse lines. Acta Neuropathol 137:437-454. https://doi.org/10.1007/s00401-019-01959-4

46. Woerman AL, Stohr J, Aoyagi A, Rampersaud R, Krejciova Z, Watts JC, Ohyama T, Patel S, Widjaja K, Oehler A et al (2015) Propagation of prions causing synucleinopathies in cultured cells. Proc Natl Acad Sci U S A 112:E4949-4958. https://doi.org/10.1073/pnas.1513426112

47. Woerman AL, Kazmi SA, Patel S, Freyman Y, Oehler A, Aoyagi A, Mordes DA, Halliday GM, Middleton LT, Gentleman SM et al (2018) MSA prions exhibit remarkable stability and resistance to inactivation. Acta Neuropathol 135:49-63. https://doi.org/10.1007/s00401-017-1762-2

48. Peng C, Gathagan RJ, Covell DJ, Medellin C, Stieber A, Robinson JL, Zhang B, Pitkin RM, Olufemi MF, Luk KC et al (2018) Cellular milieu imparts distinct pathological alpha-synuclein strains in alpha-synucleinopathies. Nature 557:558-563. https://doi.org/10.1038/s41586-018-0104-4

49. Tarutani A, Arai T, Murayama S, Hisanaga SI, Hasegawa M (2018) Potent prion-like behaviors of pathogenic alpha-synuclein and evaluation of inactivation methods. Acta Neuropathol Commun 6:29. https://doi.org/ 10.1186/s40478-018-0532-2

50. Lavenir I, Passarella D, Masuda-Suzukake M, Curry A, Holton JL, Ghetti B, Goedert M (2019) Silver staining (Campbell-Switzer) of neuronal alphasynuclein assemblies induced by multiple system atrophy and Parkinson's disease brain extracts in transgenic mice. Acta Neuropathol Commun 7:148. https://doi.org/10.1186/s40478-019-0804-5

51. Uemura N, Uemura MT, Lo A, Bassil F, Zhang B, Luk KC, Lee VM, Takahashi R, Trojanowski JQ (2019) Slow progressive accumulation of oligodendroglial alpha-synuclein (alpha-syn) pathology in synthetic alpha-syn fibrilinduced mouse models of synucleinopathy. J Neuropathol Exp Neurol 78:877-890. https://doi.org/10.1093/jnen/nlz070

52. Morgan SA, Lavenir I, Fan J, Masuda-Suzukake M, Passarella D, DeTure MA, Dickson DW, Ghetti B, Goedert M (2020) alpha-Synuclein filaments from transgenic mouse and human synucleinopathy-containing brains are major seed-competent species. J Biol Chem 295:6652-6664. https://doi. org/10.1074/jbc.RA119.012179

53. Yamasaki TR, Holmes BB, Furman JL, Dhavale DD, Su BW, Song ES, Cairns NJ, Kotzbauer PT, Diamond MI (2019) Parkinson's disease and multiple system atrophy have distinct alpha-synuclein seed characteristics. J Biol Chem 294:1045-1058. https://doi.org/10.1074/jbc.RA118.004471

54. Dhillon JS, Trejo-Lopez JA, Riffe C, McFarland NR, Hiser WM, Giasson BI, Yachnis AT (2019) Dissecting alpha-synuclein inclusion pathology diversity in multiple system atrophy: implications for the prion-like 
transmission hypothesis. Lab Invest 99:982-992. https://doi.org/10.1038/ s41374-019-0198-9

55. Schweighauser M, Shi Y, Tarutani A, Kametani F, Murzin AG, Ghetti B, Matsubara T, Tomita T, Ando T, Hasegawa K et al (2020) Structures of alphasynuclein filaments from multiple system atrophy. Nature 585:464-469. https://doi.org/10.1038/s41586-020-2317-6

56. Reyes JF, Rey NL, Bousset L, Melki R, Brundin P, Angot E (2013) Alphasynuclein transfers from neurons to oligodendrocytes. Glia 62:387-398. https://doi.org/10.1002/glia.22611

57. Inoue M, Yagishita S, Ryo M, Hasegawa K, Amano N, Matsushita M (1997) The distribution and dynamic density of oligodendroglial cytoplasmic inclusions (GCls) in multiple system atrophy: a correlation between the density of GCls and the degree of involvement of striatonigral and olivopontocerebellar systems. Acta Neuropathol 93:585-591. https://doi.org/ $10.1007 / s 004010050655$

58. Wakabayashi K, Takahashi H (2006) Cellular pathology in multiple system atrophy. Neuropathology 26:338-345. https://doi.org/10.1111/j.14401789.2006.00713.x

\section{Publisher's Note}

Springer Nature remains neutral with regard to jurisdictional claims in published maps and institutional affiliations.
Ready to submit your research? Choose BMC and benefit from:

- fast, convenient online submission

- thorough peer review by experienced researchers in your field

- rapid publication on acceptance

- support for research data, including large and complex data types

- gold Open Access which fosters wider collaboration and increased citations

- maximum visibility for your research: over 100M website views per year

At BMC, research is always in progress.

Learn more biomedcentral.com/submissions 